UDC 340

DOI https://doi.org/10.32849/2663-5313/2019.11.44

Ihor Zabokrytskyy,

Candidate of Juridical Sciences $(P h D)$,

Associate Professor of the Department of Constitutional and International Law

of the Institute of Law, Psychology and Innovative Education

of Lviv Polytechnic National University

\title{
THE FORMATION OF THE PRINCIPLE OF AMICABLE TREATMENT OF INTERNATIONAL LAW IN THE PRACTICE OF THE CONSTITUTIONAL COURT OF UKRAINE
}

The article is devoted to the the formation of the principle of amicable treatment of international law in the practice of the Constitutional Court of Ukraine as the feature of transnationalization of modern constitutionalism. The analysis of both the scientific approaches to this principle and formation of it in the practice of the Constitutional Court of Ukraine is made.

Several decisions of the Constitutional Court of Ukraine are analyzed, including the emergence of international law usage in early 2000s and following with the more formalized approach made by the Constitutional Court of Ukraine in its Decision No. 2-pn/2016 dated June 1, 2016 in the case upon the constitutional petition of the Ukrainian Parliament Commissioner for Human Rights concerning the conformity to the Constitution of Ukraine (constitutionality) of the provision of the third sentence of Article 13.1 of the Law "On Psychiatric Care" (case on judicial control over hospitalisation of disabled persons to psychiatric institution).

The conclusion is made that the formulation of this principle is a logical result of the practice already used by the Court, systematizing previous activities and pointing to the need for the application of international law in the interpretation process. This adds extra weight and causes the issue of constitutional interpretation to be taken into consideration in the process of adoption of acts of the Constitutional Court of Ukraine, since, according to the principle of settled case-law, compelling arguments are required to depart from this principle. The conclusion is made that the formulation of this principle is a logical result of the practice already used by the Court, systematizing previous activities and pointing to the need for the application of international law in the interpretation process. Therefore, the formulation in Decision No. 2-pn/2016 is considered as an exceptionally positive phenomenon, which opens a new stage in the role of international law in the activities of the Constitutional Court of Ukraine and serves as a feature of modern constitutionalism transnationalization.

Key words: principle of amicable attitude of international law, Constitutional Court of Ukraine, transnationalization of modern constitutionalism, international law, international standards of constitutionalism.

Formulation of the problem. The importance of international legal instruments using is first and foremost manifested in the application of the case-law of the European Court of Human Rights (ECtHR). It is known that in 2006 the Law of Ukraine "On Enforcement of Decisions and Application of the Practice of the European Court of Human Rights" was adopted, Art. 17 of which provides that the courts apply the Convention and the Court's case-law as a source of law when considering cases [1]. Also significant role plays the Resolution of the Plenum of the High Specialized Court of Ukraine on Civil and Criminal Cases, which sets out a number of important provisions, in particular on the need to apply the ECtHR case-law not only related to Ukraine, but also to other states, indicating that the principle of the rule of law in criminal proceedings and criminal procedural law is applied in the light of ECtHR practices, and that the use of ECtHR decisions is necessary in interpreting the Convention and its protocols as a subsequent practice of international law treaty applying (sec. 12) [2]. It is also important that the norms of international treaties that enshrine human rights and fundamental freedoms are subject to the application by the courts as direct norms (sec. 14) [2]. However, the Constitutional Court of Ukraine has only recently formulated the doctrine of amicable treatment of international law in its decisions. This principle has been studied by a number of scholars, such 
as M. Bilak, S. Shevchuk. Still, there is a need to explore the formation of the principle of amicable treatment of international law in the light of transnationalization of modern constitutionalism.

Thus, the study objective of this article is to examine the formation of the principle of amicable treatment of international law in the practice of the Constitutional Court of Ukraine as the feature of transnationalization of modern constitutionalism.

Study results. The application of ECtHR practice has also been the subject of research by a number of scholars. In particular, S. Shevchuk in his article analyzed the consistency of the case law of the European Court of Human Rights and the Constitutional Court of Ukraine (CCU), concluding that "despite the fact that courts of general jurisdiction headed by the Supreme Court of Ukraine are more adapted to the application of ECtHR practice in Ukraine (since there is a linkage to the facts of the ECtHR case, which have a direct impact on the validity and bindingness of its case law), the CCU should play a leading role in harmonizing ECtHR practices and implementing them in the Ukrainian legal system with regard to the principles of the Constitution of Ukraine supremacy and subsidiarity" [3, p. 130]. We also support the view that "the practice of the constitutional courts of Europe, including the protection and interpretation of constitutional rights and freedoms, is viewed in a broad social and political context and must be consistent with the ECtHR's practice, as democracy is based on fundamental values, rights and freedoms, which judges have to protect" [3, p. 126]. The scientist also analyzes the role of constitutional principles, pointing out that they serve as the requirements for positive legislation originating from natural law, and the content of constitutional norms is revealed through court decisions in cases concerning their application. The researcher points out that the ECtHR law is a law of principles, but it is important that when formulating the principles or applying them, the judges do not substitute objective reality for subjective visions and allow for arbitrariness in the actions, and that the judges need additional reasoning to make certain decisions, when an exclusive reference to particular rules of law is not sufficient [3, p. 126-128]. We support this position - very often references to decisions of foreign courts and /or foreign law are used to enhance argumentation and increase its legitimacy. ECtHR decisions, in this context, can serve a dual function, both as a norm of law and as a proper motivation for the application of a rule or principle, considering, in some places, the generality of the principles of constitutional law, which must be applied in each individual case, taking into account its circumstances.

An analysis of the application of the principle of international law can also be found in the work of M. Bilak, where this principle is considered, including in the light of the introduction of a constitutional complaint, indicating that "by introducing the "principle of amicable treatment of international law", the CCU implements international standards in its practice, which in fact leads to the reform of the institution of constitutional control - the CCU, which is intended to carry out its primary natural purpose - the protection of human and citizens rights. Prior to the implementation of the constitutional complaint, the CCU had, in fact, mostly resolved competing disputes between the authorities, but less the petitions of individuals, since the procedure was somewhat complicated. Such inequity against individuals does not correspond to the natural purpose of the Court, whose main function is to protect the rights and freedoms of the human and the citizen and to ensure their restoration after the violation [4, p. 15]. The author also points out that international standards emerged on the basis of the constitutional values and principles of international states, and that the values and principles of traditional Western democracies, through the consent of other states, became part of international treaties - international standards [4, p. 12]. As for the principle of amicable treatment of international law, the scholar notes that it means "the application of international and European law in interpreting the relevant constitutional provisions, in particular the constitutional norms on human rights" [4, p. 15]. As we can see, within the framework of this principle the author combines both international and European law. Recognizing that European standards remain the basis for the application of this principle (in particular, since the case law of the European Court of Human Rights remains crucial in applying this principle), however, the need for a separate reference to European law remains, and, in fact, the definition of what we are we understand by European law. It seems that in this context, we can cover both European Union law and pan-European standards, in particular within the Council of Europe and the ECtHR.

We propose to consider the case law of the Constitutional Court of Ukraine on the principle of amicable treatment of international law. Most commonly used in this context are the rulings of the European Court of Human Rights, due to the human rights activities of the Constitutional Court 
and increased attention to human rights. Searching for theacts of the Constitutional Court of Ukraine on the keywords of the "European Court" found 126 results $^{1}$, which includes different types of Constitutional Court acts both Decisions, Opinions and separate opinions of judges of the Constitutional Court of Ukraine.

In particular, the first mention is made in the Opinion of the Constitutional Court of Ukraine in the case of issuing an opinion on the conformity of the draft Law of Ukraine "On Amendments to the Constitution of Ukraine on the Results of the All-Ukrainian Referendum of 16.04.2000" [5]. However, this case does not refer to a specific ECtHR decision but to the general conclusion that the changes to Article 80 do not conform to a number of ECtHR decisions regarding the need to consistently respect the principle of the distinction between prosecution and justice (paragraph 3.2). The first reference to a specific ECtHR decision appears in the Decision on Compliance with the Constitution of Ukraine (Constitutionality) of the provisions of Articles 7, 8 of the Law of Ukraine "On State Guarantees of Recovery of Savings of Citizens of Ukraine" of 10 October 2001 [6]. In this Decision, the CCU refers to the ECtHR Decision in the case of James and other v. the United Kingdom of 21 February 1986, quoting that "Without prejudice to the right of the State to establish - within sufficiently broad discretion, in accordance with its domestic legislative, social and economic policies or for any other purpose - restriction on the use of property rights in the public interest, it should be borne in mind that such restrictions should not, however, lead to the deprivation of the possibility of such use, that is, to their complete loss" (para. 5.4). As we can see, in this case, the CCU appealed to the ECtHR's practice to reinforce its argument about the principle of proportionality.

In general, the application of ECtHR practices in the work of the Constitutional Court of Ukraine is commonplace and has begun since the early 2000s, becoming more widespread, leading to the establishment of a doctrine of amicable treatment of international law. The first mention of this principle in official acts of the Constitutional Court or separate opinions of judges is contained in the Separate Opinion of the Judge of the Constitutional Court of Ukraine O. Tupitsky. to the Decision of the Constitutional Court of Ukraine No. 2-rp/2014 dated March 14, 2014 in the case upon the constitutional petition of the acting President of Ukraine, Chairman of the Verkhovna Rada of Ukraine and Authorised Human Rights Representative of the Verkhovna

1 As of September 7, 2019.
Rada of Ukraine on conformity with the Constitution of Ukraine (constitutionality) of the Resolution of the Verkhovna Rada of the Autonomous Republic of Crimea "On conducting all-Crimean Referendum" [7]. In his Separate Opinion judge Tupitsky states that "the Constitutional Court of Ukraine consistently uses the principle of amicable treatment of international legal norms, interpreting the provisions of the Constitution and laws of Ukraine tolerantly with respect to relevant norms of international law". In addition, the judge notes that both the international treaties themselves and the practice of interpreting them serve an ancillary function and cites as an example the interpretation and definition of the content and scope of fundamental rights and principles of the rule of law enshrined in the Basic Law of Ukraine, clarifying the content of concepts and terms, etc. In the end, the judge concludes that, "In my opinion, a constitutional interpretation amicable to international law requires the perception and use of sources of international law in such a way if possible and appropriate from a methodological point of view in a particular case and consistent with the definitions Of the Constitution of Ukraine" (sec. 1).

However, the principle of amicable treatment of international law as one of the main in the activities of the CCU was formalized in two decisions adopted in 2016. The first of these was the Decision of the Constitutional Court of Ukraine № 2-rp/2016 dated June 1,2016 in the case upon the constitutional petition of the Ukrainian Parliament Commissioner for Human Rights concerning the conformity to the Constitution of Ukraine (constitutionality) of the provision of the third sentence of Article 13.1 of the Law "On Psychiatric Care" (case on judicial control over hospitalisation of disabled persons to psychiatric institution) [8]. In this case the Constitutional Court of Ukraine declared unconstitutional the provisions of the Law of Ukraine "On Psychiatric Care" regarding the hospitalization of a person, recognized as incapacitated by law, to a psychiatric institution at the request or with the consent of its guardian at the decision of a psychiatrist without judicial review. In the context of its legal position, it points to the importance of freedom as a fundamental value of an effective constitutional democracy. The Court further notes that "since Article 29 of the Constitution of Ukraine corresponds to Article 5 of the Convention, in accordance with the principle of amicable treatment of international law, the practice of interpreting and applying that Article of the Convention by the European Court of Human Rights must be taken into account in 
the consideration of this case" (para. 3 sec. 2.3) It is a very important conclusion of the CCU that if similar legal principles are contained in the European Convention for the Protection of Human Rights and Fundamental Freedoms of 1950, then the principle of amicable treatment of international law requires that these provisions be taken into account. As we can see, in comparison with Judge Tupitsky's Separate Opinion, which we have considered earlier, and which has focused on a more auxiliary function of international law in interpretation, a shift in focus on the obligation to take into account such acts and norms. Next, the CCU Decision examines the ECtHR's practice of art. 5 of the Convention, and cites a number of ECtHR decisions (Winterwerp v. The Netherlands, of 24 October 1979, McKay v. The United Kingdom, of 3 October 2006, Gorshkov v. Ukraine, of 8 November 2005), confirming the need for appropriate safeguards of mentally ill people, including judicial review and compliance with the principle of proportionality. The CCU also refers to Principles for the protection of persons with mental illness and the improvement of mental health care [9], which states that forced hospitalization or detention of patients must first be held for a short period of time set up by national law for examination and pre-treatment prior to consideration of such hospitalization or detention by a supervisory authority as a court or other independent and impartial body (Principles 16, 17). The CCU also refers to Parliamentary Assembly Recommendation No. 1235 on Psychiatry and Human Rights of January 1, 1994 [10], which states that a decision on the compulsory admission of a person to a psychiatric institution should be made by a judge setting the time limits for such admission (paragraph 7). Reference is also made to the Convention on the Rights of Persons with Disabilities of 13 December 2006 [11] and to the Recommendation of the Committee of Ministers of the Council of Europe on the legal protection of persons with mental disorders and involuntary detention as patients of 22 February 1983 No. R (83) 2 [12]. In the end, the Constitutional Court of Ukraine concludes that "the analysis of the above international documents gives grounds to conclude that it is necessary to exercise judicial control over the interference with the right to liberty and personal inviolability of a mentally ill person during his hospitalization to a psychiatric institution without his consent" (para $11 \mathrm{sec}$. 2.3.). As we can see from this decision, despite the fact that the Constitutional Court states that the provisions of the Law on Psychiatric Assistance do not comply with Articles 3, 8,
29, 55 of the Constitution of Ukraine, during the argumentation of its legal position the Court has made a considerable number of references to the European Convention on Protection of human rights and fundamental freedoms of 1950 and the practice of the ECtHR and other acts of international law. The Constitutional Court analyzed the right to liberty and security of person not by itself, but through the demnsion of international law, thereby separately crystallizing the principle of amicable treatment of international law and mentioning it in the very text of the Decision.

The reference to this principle can be also found in the Decision of the Constitutional Court of Ukraine dated September 8, 2016 № 6-rp/2016 in the case upon the constitutional petition of the Ukrainian Parliament Commissioner for Human Rights concerning the conformity to the Constitution of Ukraine (constitutionality) of the provisions of Article 21.5 of the Law of Ukraine on "On Freedom of Conscience and Religious Organisations" (the case of advance notification of public services, religious rites, ceremonies and processions) [13]. In this Decision, the CCU refers to the principle of amicable treatment of international law, which we have analyzed in previous Decision No. 2-rp/2016, stating that "in accordance with the principle of amicable treatment of international law, the practice of interpretation and application of the Convention by the European Court of Human Rights should be taken into account in its consideration of cases under the constitutional judicial procedure" (paragraph 4 sec. 2.2), after which the Court concludes that "since the provisions of Article 35 of the Constitution of Ukraine corresponds to the provisions of Article 9 of the Convention and theprovisions of Article39oftheConstitution of Ukraine - with the provisions of Article 11 of the Convention, the Constitutional Court of Ukraine, in resolving this case, takes into account the approach of the European Court of Human Rights, according to which religious meetings are a kind of peaceful meetings (paragraph 5, sec. 2.2).

So far, besides these two decisions, the Constitutional Court of Ukraine have not mentioned the principle of amicable treatment of international law in its decisions, but the judges of the Constitutional Court appealed to it in their separate opinions [14; 15], in particular in the context of methodology used by the CCU. Still, we expect that continuation of this principle development in light of growing importance of international law references and proper reasoning during constitutional interpretation. 


\section{Conclusions}

Thus, wecanmakethefollowingconclusions First, since the early 2000s, the Constitutional Court has used references to international law in its acts. This is mainly the case with the European Convention for the Protection of Human Rights and Fundamental Freedoms of 1950, which fits most organically, given its increased role in the Ukrainian legal system compared to other acts of international law (its use is more customary for Ukrainian lawyers, and the Convention itself and the ECtHR are recognized as a source of law that helps to overcome excessive formalism in trying to avoid the application of international law) and the role of human rights in the activity of the CCU. Over time, the Constitutional Court of Ukraine has increasingly resorted to acts of international law, which resulted in the formulation of the principle of amicable treatment of international law in the decision of the Constitutional Court of Ukraine No. 2-рп/2016. The formulation of this principle is a logical result of the practice already used by the Court, systematizing previous activities and pointing to the need for the application of international law in the interpretation process. This adds extra weight and causes the issue of constitutional interpretation to be taken into consideration in the process of adoption of acts of the Constitutional Court of Ukraine, since, according to the principle of settled case-law, compelling arguments are required to depart from this principle. Therefore, we consider its formulation in Decision No. 2-рп/2016 as an exceptionally positive phenomenon, which opens a new stage in the role of international law in the activities of the Constitutional Court of Ukraine and serves as a feature of modern constitutionalism transnationalization.

\section{References:}

1. Про виконання рішень та застосування практики Європейського суду з прав людини : Закон України від 23 лютого 2006 p. URL: http:// zakon5.rada.gov.ua/laws/show/3477-15.

2. Про застосування судами міжнародних договорів України при здійсненні правосуддя : Постанова Пленуму Вищого Спеціалізованого Суду України з розгляду цивільних і кримінальних справ № 13 від 19 грудня 2014 p. URL: https://zakon.rada.gov.ua/laws/show/ v0013740-14

3. Шевчук. Узгодженість практики Європейського суду з прав людини та Конституційного Суду України. Вісник Конституиійного Суду України. 2011. № 4-5. С. 122-130.

4. Білак М.В. Значення угоди про асоціацію з СС: нові виклики для конституційного порядку чи послаблення позиції Основного Закону. Наукові записки НаУКМА. Серія «Юридичні науки». 2017. T. 193. C. $12-16$.

5. Висновок Конституційного Суду України у справі за зверненням Верховної Ради України про надання висновку щодо відповідності проекту Закону України «Про зміни до Конституції України за результатами всеукраїнського референдуму 16.04 .2000 року», поданого народними депутатами України, вимогам статей 157 і 158 Конституції України (справа про внесення змін до Конституції України за ініціативою народних депутатів України) від 11 липня 2000 р. Справа № 1-39/2000. URL: https://zakon.rada.gov.ua/ laws/show/v002v710-00/sp:max100.

6. Рішення Конституційного Суду України у справі за конституційним поданням Уповноваженого Верховної Ради України з прав людини щодо відповідності Конституції України (конституційності) положень статей 7, 8 Закону України «Про державні гарантії відновлення заощаджень громадян України», за конституційним зверненням Воробйова В.Ю., Лосєва С.В. та інших громадян щодо офіційного тлумачення положень статей 22, 41, 64 Конституції України (справа про заощадження громадян) від 10 жовтня 2001 р. № 13-рп/2001. URL: https://zakon.rada.gov.ua/laws/ show/v013p710-01/sp:max100.

7. Окрема Думка судді Конституційного Суду України Тупицького О.М. стосовно Рішення Конституційного Суду України у справі за конституційними поданнями виконуючого обов'язки Президента України, Голови Верховної Ради України та Уповноваженого Верховної Ради України з прав людини щодо відповідності Конституції України (конституційності) Постанови Верховної Ради Автономної Республіки Крим «Про проведення загальнокримського референдуму» (справа про проведення місцевого референдуму в Автономній Республіці Крим). URL: https://zakon.rada.gov.ua/ laws/show/nb02d710-14/sp:max100.

8. Рішення Конституційного Суду України у справі за конституційним поданням Уповноваженого Верховної Ради України з прав людини щодо відповідності Конституції України (конституційності) положення третього речення частини першої статті 13 Закону України «Про психіатричну допомогу» (справа про судовий контроль за госпіталізацією недієздатних осіб до психіатричного закладу) від 1 червня 2016 р. № 2-рп/2016. URL: https://zakon.rada.gov.ua/laws/show/v002p 710-16/sp:max100.

9. Principles for the protection of persons with mental illness and the improvement of mental health care. Adopted by General Assembly resolution 46/119 of 17 December 1991. URL: https://www. who.int/mental health/policy/en/UN Resolution on protection of persons with mental illness.pdf.

10. Parliamentary Assembly. Recommendation 1235 (1994) Psychiatry and human rights. URL: http://assembly.coe.int/nw/xml/XRef/Xref-XML2HTML-en.asp?fileid=15269\&lang=en.

11. Convention on the Rights of Persons with Disabilities (CRPD). URL: https://www. 
un.org/development/desa/disabilities/convention-on-the-rights-of-persons-with-disabilities.html.

12. Recommendation No. R (83) 2 of the Committee of Ministers of the Council of Europe on the legal protection of persons suffering from mental disorders placed as involuntarty pacients. URL: https:// www.justice.gov.sk/Dokumenty/Ochrana_pred_ mucenim/a_ODPORUCANIA/recR(83)2.pdf

13. Рішення Конституційного Суду України у справі за конституційним поданням Уповноваженого Верховної Ради України з прав людини щодо відповідності Конституції України (конституційності) положень частини п'ятої статті 21 Закону України «Про свободу совісті та релігійні організації" (справа про завчасне сповіщення про проведення публічних богослужінь, релігійних обрядів, церемоній та процесій)» від 8 вересня 2016 p. № 6-pп/2016. URL: https://zakon.rada.gov.ua/ laws/show/v006p710-16/sp:max100.
14. Окрема Думка судді Конституційного Суду України Литвинова О.М. стосовно Ухвали Великої палати Конституційного Суду України про закриття конституційного провадження у справі за конституційним поданням Уповноваженого Верховної Ради України з прав людини щодо відповідності Конституції України (конституційності) окремого положення частини дев'ятої статті 46 Закону України «Про Кабінет Міністрів України». URL: https://zakon.rada.gov.ua/laws/ show/n008d710-18/sp:max10.

15. Окрема Думка судді Конституційного Суду України Лемака В.В. стосовно Рішення Конституційного Суду України у справі за конституційним поданням 59 народних депутатів України щодо відповідності Конституції України (конституційності) статті 368-2 Кримінального кодексу України. URL: https://zakon.rada.gov.ua/laws/ show/nd01d710-19/sp:max100.

Стаття присвячена формуванню принципу дружнього ставлення до міжнародного права в практиці Конституційного Суду України як ознаки транснаціоналізаиіі сучасного конститучіоналізму. Проведено аналіз як наукових підходів до иього приниипу, так $і$ формування його в практиці Конституиійного Суду України.

Проаналізовано декілька рішень Конституиійного Суду України, у тому числі появу використання міжнародного права на початку 2000-х років $і$ більш формалізований підхід, прийнятий Конституиійним Судом України в Рішенні від 1 червня 2016 року № 2-рn/2016 у справі за конституиійним поданням Уповноваженого Верховної Ради України з прав людини щодо відповідності Конституиій України (конституиійності) положення третього речення частини 1 статті 13 Закону України «Про психіатричну допомогу» (справа про судовий контроль за госпіталізацією недієздатних осіб до психіатричного закладу).

Зроблено висновок, що формулювання ивого приниипу є логічним результатом практики, яку вже використовує Суд, систематизуючи попередню діяльність і вказуючи на необхідність застосування міжнародного права в процесі тлумачення. Це додає йому додаткової ваги і змушує його враховувати під час конституиійного тлумачення в прочесі прийняття актів Конституиійного Суду Украйни, оскільки, згідно з приниипом усталеної судової практики, необхідні переконливі аргументи, щоб відступити від иього приниипу. Тому формулювання в Рішенні № 2-рп/2016 розглядається як виключно позитивне явище, що відкриває новий етап у ролі міжнародного права в діяльності Конституційного Суду України та є ознакою сучасної транснаціоналізації конституиіоналізму.

Ключові слова: принцип дружнього ставлення до міжнародного права, Конституційний Суд України, транснаціоналізація сучасного конституціоналізму, міжнародне право, міжнародні стандарти конституціоналізму. 